\title{
Allium sativum, Rosmarinus officinalis, and Salvia officinalis Essential Oils: A Spiced Shield against Blowflies
}

\author{
Stefano Bedini ${ }^{1}{ }^{\oplus}$, Salvatore Guarino ${ }^{2}{ }^{(0}$, Maria Cristina Echeverria ${ }^{3}\left(\mathbb{C}\right.$, Guido Flamini ${ }^{4}(\mathbb{D}$, \\ Roberta Ascrizzi ${ }^{4}$ (D), Augusto Loni ${ }^{1}$ and Barbara Conti ${ }^{1, *(D)}$ \\ 1 Department of Agriculture, Food and Environment- University of Pisa, via del Borghetto 80, 56126 Pisa, \\ Italy; stefano.bedini@unipi.it (S.B.); augusto.loni@unipi.it (A.L.) \\ 2 Institute of Biosciences and Bioresources (IBBR), National Research Council of Italy (CNR), \\ Corso Calatafimi 414, 90129 Palermo, Italy; salvatore.guarino@ibbr.cnr.it \\ 3 Facultad de Ingeniería en Ciencias Agropecuarias y Ambientales. Universidad Técnica del Norte, \\ Av 17 de Julio 5-21, Ibarra 100105, Ecuador; mecheverria@utn.edu.ec \\ 4 Department of Pharmacy, University of Pisa, Via Bonanno 6, 56126 Pisa, Italy; guido.flamini@unipi.it (G.F.); \\ roberta.ascrizzi@gmail.com (R.A.) \\ * Correspondence: barbara.conti@unipi.it
}

Received: 4 February 2020; Accepted: 20 February 2020; Published: 25 February 2020

\begin{abstract}
Blowflies are known vectors of many foodborne pathogens and unintentional human ingestion of maggots by meat consumption may lead to intestinal myiasis. In fact, the control of insect pests is an important aspect of industrial and home-made food processing and blowflies (Diptera: Calliphoridae), which are among the most important pests involved in the damage of meat products. Most spices, largely used in food preparations and industry, contain essential oils that are toxic and repellent against insects and exert antimicrobial activity. In this study, we assessed the electro-antennographic responses, the oviposition deterrence, the toxicity, and the repellence of the essential oils (EOs) of Allium sativum L., Salvia officinalis L., and Rosmarinus officinalis L. against the blowfly Calliphora vomitoria $\mathrm{L}$. We tested the EOs antibacterial and antifungal properties and the efficacy of an A. sativum EO-charged mist sprayed in the tunnel entryway of a meat processing room to form an olfactive barrier against the entrance of flies. The results showed that the EOs are perceived by female blowfly' antennae and exert an evident repellent activity against them completely deterring the oviposition for up to $24 \mathrm{~h}$ starting from the concentration of $2.5 \mu \mathrm{L} \mathrm{cm}^{-2} \mathrm{EO}$. The EOs also exhibited toxic activity by both topical application $\left(\mathrm{LD}_{50}\right.$ from 0.44 to $1.97 \mu \mathrm{L}$ insect $\left.^{-1}\right)$ and fumigation ( $\mathrm{LC}_{50}$ from 1.76 to $31.52 \mu \mathrm{L} \mathrm{L}^{-1}$ ) against adults of $C$. vomitoria and were able to exert a clear antimicrobial activity toward pathogens. Lastly, the EO-charged mist was able to reduce by about $40 \%$ the presence of Calliphoridae in the meat processing room of a dry-ham factory.
\end{abstract}

Keywords: blowflies; essential oil; repellent; insecticidal; bactericidal; fungicidal

\section{Introduction}

Blowflies (Diptera: Calliphoridae) are problematic synanthropic insect pests, which are important vectors of many pathogens. These flies, feeding on excrement and decaying organic matter, can easily transmit human and domestic animal pathogens to food and surfaces, causing the spread of foodborne illnesses and other diseases [1-3]. Blowflies are strongly attracted by the fresh meat on which they lay their eggs, which causes infestation by maggots and a rapid decaying due to the microorganisms they spread. In addition, in case of unintentional ingestion, blowfly maggots may also lead to human intestinal myiasis, an uncommon but severe pathology $[4,5]$. 
Besides fresh meat products, blowflies, especially the bluebottle fly Calliphora vomitoria L., represents a problem for the dry-cured meat and fish industry, as well. C. vomitoria infestation in the meat or fish industry is due to several peculiar characteristics of the species and, in particular, to its highly developed olfactory organs [6]. The infestation is often severe, due to the ability of females to lay hundreds of eggs in a very short time and to its very accelerated metabolism rate, which allows the fly to be active at low temperatures $[7,8]$.

A traditional method to prevent pest infestation is the addition of plant-derived spices to the meat during its processing [9-11]. Spices have found wide applications both in the traditional food preparations and in the food industry for their flavouring, colouring, and, above all, preservative properties. Many compounds isolated from aromatic plants, such as essential oils (EOs), have shown antimicrobial activity against some of the most common microorganisms that affect the food quality and shelf-life as well as various beneficial effects for the consumers, including antioxidant and anti-inflammatory activities [12,13]. Even though EOs have also been proved to be effective as insecticides and repellents against food-stuff insect pests [14-18], very few information is available about their efficacy to protect fresh and processed meat from blowflies.

The aim of this work was to test the essential oils of Allium sativum L. (Amaryllidaceae), Rosmarinus officinalis L. (Lamiaceae), and Salvia officinalis L. (Lamiaceae), three aromatic plants commonly used in food processing, against the blowfly C. vomitoria. For this purpose, after determining their chemical composition, the EOs were first tested to determine the olfactory responsiveness of $C$. vomitoria by electro-antennography. Then we performed laboratory tests to determine their oviposition deterrence, ovicidal, and adulticidal effect. We tested the EOs for their antibacterial and antifungal properties against several common human pathogens. Lastly, we evaluated the repellence of a $A$. sativum EO-charged mist used as an olfactive barrier against the entrance of flies in a meat processing room of a dry-ham factory.

\section{Materials and Methods}

\subsection{Insects}

Larvae of the bluebottle fly C. vomitoria were purchased from a commercial supplier (Fish Company Arco Sport, Cascina PI, Italy). The larvae were fed with beef liver and maintained at room temperature until pupation. The pupae were held in cages until the emergence of the adults, which were provided with a sugar-yeast diet (sugar and yeast 1:1) to provide the proteins amount necessary to stimulate oviposition $[19,20]$ and water ad libitum. Species identification of the emerged adults was confirmed by an expert dipterologist (Alfio Raspi, former Professor, Department of Agriculture, Food and Environment, University of Pisa). C. vomitoria pupae and adults were kept under laboratory conditions $\left(23{ }^{\circ} \mathrm{C}, 65 \pm 5 \%\right.$ R.H., natural photoperiod).

\subsection{Essential Oils GC-MS Analysis}

A. sativum, R. officinalis, and S. officinalis EOs were purchased from Vis Medicatrix Naturae s.r.l. (Florence, Italy). The EOs were chemically analysed by gas chromatography-electron impact mass spectroscopy (GC-EIMS) with a Varian CP-3800 gas chromatograph, equipped with a HP-5 capillary column $(30 \mathrm{~m} \times 0.25 \mathrm{~mm}$, coating thickness $0.25 \mu \mathrm{m})$ and a Varian Saturn 2000 ion trap mass detector. The analytical conditions were as follows: injector and transfer line temperatures $220^{\circ} \mathrm{C}$ and $240^{\circ} \mathrm{C}$ respectively, oven temperature programmed from $60^{\circ} \mathrm{C}$ to $240{ }^{\circ} \mathrm{C}$ at $3^{\circ} \mathrm{C} / \mathrm{min}$, carrier gas helium at $1 \mathrm{~mL} / \mathrm{min}$, injection of $0.2 \mu \mathrm{L}$ (10\% hexane solution), and split ratio 1:30. Constituents identification was based on a comparison of retention times with those of authentic samples by comparing their LRIs with the series of $n$-hydrocarbons and using computer matching against commercial [21,22] and home-made library mass spectra (built up from pure substances and components of known oils and mass spectra literature data) [22,23]. 


\subsection{Electroantennography $(E A G)$}

The A. sativum, R. officinalis, and S. officinalis EOs were tested by electroantennogram recordings on C. vomitoria females (4-7 days old). The EOs were serially diluted 1:10 with ethyl alcohol (Sigma Aldrich, 99\%) up to the concentration of $1 \mu \mathrm{g} \mu \mathrm{L}^{-1}$. One $\mu \mathrm{L}$ of each tested EO was used in aliquots ranging from 0.1 to $1000 \mu \mathrm{g}$ (pure). The stimuli were pipetted on a piece of filter paper (Whatman No. 1), exposed to air for 5 min to allow the solvent to evaporate, and then inserted into a glass Pasteur pipette. C. vomitoria females used for this experiment were anesthetized with $\mathrm{CO}_{2}$ and their head was cut at the base. In order to avoid early saturation of the antennae, stimuli were tested from the lowest to the highest dose. For electroantennography (EAG) preparation glass capillary tubes filled with $0.1 \mathrm{M} \mathrm{KCl}$ solution were connected to the silver wire recording and reference electrodes. The recording electrode was placed gently by touching the tip of one randomly selected antenna, while the reference electrode was placed at the base of the head. A stimulus-flow controller (model CS-05, Synthech, the Netherlands) was used to generate a $3.0 \mathrm{~s}$ stimulus at a 1-min interval with a flow rate of $1.5 \mathrm{~L} \mathrm{~min}^{-1}$. The antennal responses were passed through a high impedance amplifier (model IDAC-4, Synthech, Hilversum, the Netherlands) and recorded with specialized software (Synthech). At the beginning and the end of the stimulation of the antenna with each plant essential oil, $1 \mu \mathrm{L}$ of pure ethyl alcohol was puffed as a control stimulus. The same antenna was used to test all of the EOs at all the concentrations. Each EO was tested on 10 female antennae using one antenna per fly $(\mathrm{N}=10)$. The sequence of the tested essential oil was randomized.

\subsection{Oviposition Deterrence}

The oviposition deterrence of the essential oils against $C$. vomitoria was evaluated by exposing fresh meat treated with the EOs to C. vomitoria mature females in a cage. In detail, 150 C. vomitoria unsexed adults 10 to 14 -days-old were placed into a cage $(47.5 \mathrm{~L} \times 47.5 \mathrm{~W} \times 93 \mathrm{~cm} \mathrm{H})$ (model BugDorm-44590 Insect Rearing Tent) with net sides and front mesh ends. The cage was collocated under a bank of fluorescent lamps to provide even lighting and were maintained at about $23{ }^{\circ} \mathrm{C}$ and $65 \pm 5 \%$ R.H. A beaker containing $500 \mathrm{~mL}$ of water, covered by a net, was placed in the cage to provide humidification. Oviposition stimulus was provided by polyethylene embedding moulds (Peel-A-Way ${ }^{\circledR}$ Embedding Mold (Truncated - T12) (Polysciences Europe GmbH, Hirschberg an der Bergstrasse, Germany) filled by pork meat $(5 \mathrm{~g})$ mixed with $1 \mathrm{~mL}$ of water to prevent desiccation. The meat surface $\left(4.84 \mathrm{~cm}^{-2}\right) \mathrm{was}$ gently pressed and treated by a glass nebulizer with $100 \mu \mathrm{L}$ of ethanolic EO solution at $0 \%$ (control), $0.5 \%, 1 \%$, and $2 \%$, corresponding to $0,1.2,2.5$, and $5 \mu \mathrm{L} \mathrm{cm}^{-2}$ of meat. At each corner of the cage, four meat-moulds treated with the four different EO concentrations $\left(0,1.2,2.5\right.$, and $\left.5 \mu \mathrm{L} \mathrm{cm}{ }^{-2}\right)$ were placed on a Petri dish lid about $3 \mathrm{~cm}$ from the edge of the cage. To minimize any border effect, the reciprocal disposition of the $\mathrm{EO}$ concentrations was maintained at the four cage corners. A scheme of the disposition of the meat-moulds inside of the cage is reported in Figure S1.

To evaluate the intensity and the lasting effect of the Eos' protection, the eggs laid onto the meat were counted after 3, 24, 48, and 72 h. Eggs were counted under a dissection microscope. The number of eggs laid in large aggregates was counted by an analytical balance equipped with a piece counter function. The number of eggs laid onto the four meat moulds treated with the same EO concentration were summed together. The experiment was performed with three replicates (one cage for replicate).

Oviposition deterrence was evaluated by calculating the Oviposition Activity Index (OAI) using the formula below.

$$
\mathrm{OAI}=(\mathrm{NT}-\mathrm{NC}) /(\mathrm{NT}+\mathrm{NC})
$$

where NT $=$ total number of eggs on the treated meat and $\mathrm{NC}=$ total number of eggs on the control meat [24]. For OAI values $\leq-0.3$, the EO was considered as repellent [25]. 


\subsection{Ovicidal Bioassay}

The toxicity of the essential oils against the C. vomitoria eggs was evaluated by exposing freshly laid eggs to several concentrations of the three EOs. One-hundred eggs were placed in a petri dish on filter paper ( $4 \mathrm{~cm} \varnothing$ ) treated with $100 \mu \mathrm{L}$ of $0.25 \%, 0.50 \%, 0.75 \%, 1.00 \%, 2.00 \%, 5.00 \%$, and $10.00 \% \mathrm{EtOH}$ solutions of the EOs corresponding to $0.02,0.04,0.06,0.08,0.16,0.40$, and $0.80 \mu \mathrm{L} \mathrm{cm}^{-2}$. As a form of control treatment, 100 eggs were placed on filter paper treated with $100 \mu \mathrm{L}$ of EtOH only. For all the treatments, before placing the eggs, ethanol was evaporated by exposing the treated paper to an airflow for 3-5 min. For each concentration, three replicates, with each one of 100 eggs, were performed.

\subsection{Adulticidal Bioassays}

The toxicity of the essential oils against the C. vomitoria adults was evaluated both by fumigation and topical application bioassays. For the fumigation bioassay, 10 unsexed adult flies were placed in an airtight glass jar $(300 \mathrm{~mL})$ with a screw lid. A piece of filter paper was adhered inside the lid. Furthermore, $100 \mu \mathrm{L}$ of $0.25 \%, 0.5 \%, 1 \%, 5 \%$, and $10 \%$ EtOH solutions of the EOs, corresponding to 1, 2, 3,17 , and $33 \mu \mathrm{L} \mathrm{L}^{-1}$ of air, were applied to the filter paper. The treated filter paper was protected from direct contact with the insect by a thin layer of sterile gauze. The control jars were treated with $100 \mu \mathrm{L}$ of EtOH only. For all the treatments, before placing the lid, ethanol was evaporated by exposing the treated paper to an airflow for 3-5 min. The jars were further sealed with Parafilm and maintained under laboratory conditions $\left(23^{\circ} \mathrm{C}, 65 \pm 5 \%\right.$ R.H.). Each test was replicated three times and mortality was checked at $24 \mathrm{~h}$. As for the toxicity tests by topical application, the three EOs were tested against 7-10 days-old adults of C. vomitoria. Flies were treated by a Burkard hand micro-applicator equipped with a one-mL syringe. Two $\mu \mathrm{L}$ of $10 \%, 20 \%$, and $40 \%$ EtOH solutions of the EOs (corresponding to 0.2 , 0.4 , and $0.8 \mu \mathrm{L}_{\text {insect }}{ }^{-1}$ ) were applied on the thorax of 10 unsexed adult flies [26]. Three replicates (30 treated flies) were run for each dose. Control flies were treated with $2 \mu \mathrm{L}$ of EtOH only. Insects were maintained in Plexiglas cages of $20 \mathrm{~cm}$ of diameter and $30 \mathrm{~cm}$ long (10 insects per cage) with water and sugar ad libitum under laboratory conditions. Mortality of the flies was checked after $24 \mathrm{~h}$ and values were corrected using the Abbott formula [27].

\subsection{Antimicrobial Assays}

The EOs were individually tested against Escherichia coli ATCC 10536, Staphylococcus aureus (ATCC BAA-1026), Bacillus subtilis (ATCC 11774), Salmonella enterica subsp. enterica serovar Abaetetuba (ATCC 35640), Pseudomonas aeruginosa (ATCC 15442), and Candida albicans (ATCC 10231). All the strains were purchased from the American Type of Culture Collection (ATCC, Manassan, USA) and maintained in the Laboratories of the Universidad Técnica del Norte, Ecuador. E. coli, S. aureus, P. aeruginosa, and B. subtilis strains were grown on nutrient agar. C. albicans strain was grown on malt agar. S. enterica was grown on trypticase soy agar.

The antibacterial activity of the EOs was determined by assessing the minimum inhibitory concentration (MIC) and minimum lethal concentration (MLC) following the method described by

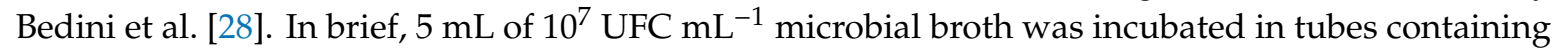
$50 \mu \mathrm{L}$ of decreasing concentrations of the $\mathrm{EO}(10,5,2.5,1.25$, and $0.63 \mu \mathrm{L}$ per tube). The MIC was estimated as the lowest EOs concentration that inhibited any visible microbial growth [29]. The MLC was calculated as the highest EO dilution at which no growth occurred on the plates. Microorganisms' death was checked by sub-culturing $0.1 \mathrm{~mL}$ of the cell suspensions from the tubes by showing no growth on nutrient agar plates for bacteria and on malt agar plates for yeast. Three repetitions of each treatment were made.

\subsection{EO-Charged Mist Assay}

The A. sativum EO, which resulted as the most effective EOs in the oviposition deterrence, was tested as an active ingredient in a repellent mist sprayed by an automatic system. The repellent 
activity of the EO-charged mist was tested in a ham factory (Micheletti S. r. 1., Lammari, Lucca, Italy). A stable water emulsion of the A. sativum EO was obtained by mixing the EO with 1\% Tween 80 water solution to a final EO concentration of $1 \%$. The emulsion was automatically mixed with tap water and sprayed by an automatic system (Gardensystem, Freezanz System Srls, Pisa, Italy) through nine 0.3-mm brass misting nozzles located in order to form an olfactory barrier (EO-charged mist) at the entrance tunnel $(5 \mathrm{~L} \times 2.6 \mathrm{~W} \times 4 \mathrm{H} \mathrm{m})$ of the meat processing room. The spraying system was active from 6 a.m. to 18 p.m. for 5 s every $10 \mathrm{~min}$. The quantity of the emulsion sprayed was $100 \mathrm{~mL} \mathrm{day}^{-1}$. The effectiveness of the mist as a barrier against the entrance of the flies was assessed by a fly light trap (Mantis $1 \times 2$, PestWest U.S.A. LLC., Sarasota, USA) equipped with a glue board $(419 \times 23 \mathrm{~cm})($ Boacha 850, PestWest U.S.A. LLC., Sarasota, USA) that was placed inside the meat processing room. The glue board of the trap was removed weekly and transported in the lab for identifying the trapped Diptera. A $0.1 \%$ Tween 80 water solution spray (Control mist) was used as control treatment. The EO-charged mist or the Control mist treatments were performed every other week for 6 weeks to obtain three replicates for each treatment. The identification of captured specimens belonging to Muscidae and Calliphoridae was performed by adopting the key of Oosterbroek [30] for European families of Diptera.

\subsection{Statistics and Data Analyses}

Log-probit regressions were used to assess the toxicity of the EOs against C. vomitoria adults. $\mathrm{LD}_{50}$ and the $\mathrm{LC}_{50}$ values of the two EOs were reported as toxicological endpoints for comparison. Significant differences between the toxicity regressions were determined by estimating confidence intervals of the relative median potency ( $\mathrm{rmp}$ ). Differences between toxicity values were considered statistically significant when values in the $95 \%$ confidence interval of relative median potency analyses were $\neq 1.0$. Oviposition deterrence and toxicity percentage data were transformed into arcsine values before statistical analysis. Oviposition deterrence data were processed by one-way between-groups univariate analysis of covariance (ANCOVA) with the EO as a fixed factor. The EOs concentration and the time of exposition were considered as covariates in the model and their effect was controlled in the analysis. Post hoc comparisons were performed using Bonferroni corrections for multiple comparisons. The estimated marginal (EM) means of the insect pests' mortality are reported. Electro-antennographic data were analysed by performing a two-way ANOVA with the EO and the concentration as fixed factors after normalizing the data for the control. Differences between solvent and the EOs concentrations among each EO were assessed by one-way ANOVA, which was followed by a Fisher's least significant difference (LSD) test. The differences in the sizes of the inhibitory zones formed by the EOs against different microbial strains were tested by the Kruskal-Wallis test and the means were separated by Dunn-Bonferroni pairwise comparisons. The independent-samples t-test (two-tailed) was used to assess differences between the mean number of flies trapped during the treatment with the essential oil mist (EO-charged mist) and tween-80 only (Control) during the EO-charged mist assay. The ANOVA and ANCOVA assumptions of variance homogeneity and normality were confirmed by Levene's test and the Shapiro-Wilk test, respectively. Statistics were performed by SPSS 22.0 software (IBM SPSS Statistics, Armonk, North Castle, NY, USA).

\section{Results}

\subsection{Chemical Composition of the EOs}

The complete compositions of the three EOs are reported in Table 1. Overall, 99 compounds were identified. The EOs of $R$. officinalis and S. officinalis, both belonging to the Lamiaceae family, showed compositional similarities while $A$. sativum EO exhibited a completely different profile. 
Table 1. Chemical composition of Allium sativum, Rosmarinus officinalis, and Salvia officinalis essential oils.

\begin{tabular}{|c|c|c|c|c|}
\hline \multirow{2}{*}{ Compounds } & \multirow{2}{*}{ 1.r.i. ${ }^{a}$} & \multicolumn{3}{|c|}{ Relative Abundance (\%) } \\
\hline & & A. sativum & R. officinalis & S. officinalis \\
\hline (Z)-3-hexen-1-ol & 855 & $-b$ & $\operatorname{Tr}{ }^{c}$ & - \\
\hline (Z)-salvene & 855 & - & - & $\operatorname{tr}$ \\
\hline (E)-2-hexenal & 856 & - & $\operatorname{tr}$ & - \\
\hline diallyl sulfide & 866 & 5.5 & - & - \\
\hline$(E)$-salvene & 866 & - & - & $\operatorname{tr}$ \\
\hline 2,3-dimethyl thiophene & 901 & 0.3 & - & - \\
\hline santolina triene & 909 & - & $\operatorname{tr}$ & - \\
\hline methyl-2-propenyl disulfide & 920 & 3.6 & - & - \\
\hline tricyclene & 928 & - & 0.2 & 0.7 \\
\hline$\alpha$-thujene & 931 & - & 0.3 & 0.7 \\
\hline (Z)-methylpropenyl disulfide & 932 & 0.2 & - & - \\
\hline (E)-methylpropenyl disulfide & 940 & 0.2 & - & - \\
\hline$\alpha$-pinene & 941 & - & 9.8 & 4.6 \\
\hline camphene & 954 & - & 4.2 & 5.7 \\
\hline thuja-2,4(10)-diene & 959 & - & $\operatorname{tr}$ & - \\
\hline dimethyl trisulfide & 975 & 0.8 & - & - \\
\hline sabinene & 976 & - & $\operatorname{tr}$ & $\operatorname{tr}$ \\
\hline 1-octen-3-ol & 980 & - & $\operatorname{tr}$ & - \\
\hline$\beta$-pinene & 982 & - & 5.6 & 2.5 \\
\hline 3-octanone & 987 & - & $\operatorname{tr}$ & - \\
\hline myrcene & 993 & - & 1.5 & 1.1 \\
\hline$\alpha$-phellandrene & 1005 & - & 0.3 & 0.2 \\
\hline$\delta$-3-carene & 1011 & - & $\operatorname{tr}$ & - \\
\hline$\alpha$-terpinene & 1018 & - & 0.8 & $\operatorname{tr}$ \\
\hline p-cymene & 1027 & - & 1.8 & 1.1 \\
\hline limonene & 1032 & - & - & $\operatorname{tr}$ \\
\hline 1,8-cineole & 1034 & - & 41.2 & 11.9 \\
\hline$(Z)$ - $\beta$-ocimene & 1042 & - & $\operatorname{tr}$ & - \\
\hline$(E)$ - $\beta$-ocimene & 1052 & - & $\operatorname{tr}$ & - \\
\hline$\gamma$-terpinene & 1062 & - & 0.9 & 1.8 \\
\hline cis-sabinene hydrate & 1070 & - & $\operatorname{tr}$ & $\operatorname{tr}$ \\
\hline trans-linalool oxide (furanoid) & 1076 & - & $\operatorname{tr}$ & $\operatorname{tr}$ \\
\hline camphenilone & 1078 & - & $\operatorname{tr}$ & - \\
\hline diallyl disulfide & 1082 & 16.1 & - & - \\
\hline terpinolene & 1088 & - & 0.5 & 0.9 \\
\hline$p$-cymenene & 1089 & - & $\operatorname{tr}$ & - \\
\hline linalool & 1101 & - & 1.4 & - \\
\hline (E)-1-allyl-2-(prop-1-en-1-yl) disulfane & 1103 & 0.7 & - & - \\
\hline$\alpha$-thujone & 1104 & - & - & 22.2 \\
\hline (Z)-1-allyl-2-(prop-1-en-1-yl) disulfane & 1107 & 0.6 & - & - \\
\hline$\beta$-thujone & 1118 & - & - & 5.5 \\
\hline exo-fenchol & 1119 & - & $\operatorname{tr}$ & - \\
\hline$\alpha$-campholenal & 1125 & - & $\operatorname{tr}$ & - \\
\hline trans-pinocarveol & 1139 & - & $\operatorname{tr}$ & - \\
\hline nopinone & 1140 & - & $\operatorname{tr}$ & - \\
\hline methyl allyl trisulfide & 1142 & 9.5 & - & - \\
\hline camphor & 1143 & - & 11.7 & 16.2 \\
\hline 4-methyl-1,2,3-trithiolane & 1154 & 0.9 & - & - \\
\hline trans-pinocamphone & 1162 & - & $\operatorname{tr}$ & - \\
\hline pinocarvone & 1163 & - & $\operatorname{tr}$ & - \\
\hline borneol & 1165 & - & 4.7 & 4.2 \\
\hline cis-pinocamphone & 1175 & - & $\operatorname{tr}$ & - \\
\hline 4-terpineol & 1178 & - & 1.1 & 0.6 \\
\hline$p$-cymen-8-ol & 1183 & - & $\operatorname{tr}$ & - \\
\hline
\end{tabular}


Table 1. Cont.

\begin{tabular}{|c|c|c|c|c|}
\hline \multirow{2}{*}{ Compounds } & \multirow{2}{*}{ 1.r.i. ${ }^{a}$} & \multicolumn{3}{|c|}{ Relative Abundance (\%) } \\
\hline & & A. sativum & R. officinalis & S. officinalis \\
\hline$\alpha$-terpineol & 1189 & - & 3.3 & 0.1 \\
\hline myrtenol & 1193 & - & - & $\operatorname{tr}$ \\
\hline decanal & 1204 & - & $\operatorname{tr}$ & - \\
\hline verbenone & 1205 & - & $\operatorname{tr}$ & - \\
\hline 2-vinyl-4H-1,3-dithiine & 1206 & 0.6 & - & - \\
\hline dimethyl tetrasulfide & 1210 & 0.8 & - & - \\
\hline endo-fenchyl acetate & 1223 & - & - & $\operatorname{tr}$ \\
\hline isobornyl formate & 1232 & - & $\operatorname{tr}$ & - \\
\hline 3-methyl-3-hexen-1-yl butanoate & 1236 & - & - & $\operatorname{tr}$ \\
\hline carvotanacetone & 1248 & - & - & $\operatorname{tr}$ \\
\hline isobornyl acetate & 1285 & - & 1.5 & 2.8 \\
\hline trans-sabinyl acetate & 1291 & - & - & $\operatorname{tr}$ \\
\hline diallyl trisulfide & 1297 & 23.1 & - & - \\
\hline (Z)-1-allyl-3-(prop-1-en-1-yl) trisulfane & 1329 & 0.2 & - & - \\
\hline (E)-1-allyl-3-(prop-1-en-1-yl) trisulfane & 1346 & 0.6 & - & - \\
\hline$\alpha$-cubebene & 1351 & - & - & $\operatorname{tr}$ \\
\hline S-methyl-1,2,3,4-tetrathiane & 1364 & 1.0 & - & - \\
\hline$\alpha$-ylangene & 1372 & - & $\operatorname{tr}$ & - \\
\hline$\alpha$-copaene & 1376 & - & $\operatorname{tr}$ & 0.2 \\
\hline S-propylpropane thiosulfonate & 1388 & 6.7 & - & - \\
\hline methyl eugenol & 1403 & - & $\operatorname{tr}$ & - \\
\hline (Z)-caryophyllene & 1405 & - & $\operatorname{tr}$ & $\operatorname{tr}$ \\
\hline$\beta$-caryophyllene & 1420 & - & 7.4 & 7.9 \\
\hline 1-(1-(methylthio) propyl)-2-propyl disulfane & 1431 & 0.5 & - & - \\
\hline aromadendrene & 1445 & - & - & $\operatorname{tr}$ \\
\hline dimethyl pentasulfide & 1450 & 0.3 & - & - \\
\hline$\alpha$-humulene & 1456 & - & 1.2 & 8.3 \\
\hline (E)- $\beta$-farnesene & 1460 & - & $\operatorname{tr}$ & - \\
\hline alloaromadendrene & 1461 & - & - & $\operatorname{tr}$ \\
\hline trans-cadina-1(6),4-diene & 1470 & - & - & $\operatorname{tr}$ \\
\hline$\gamma$-muurolene & 1477 & - & $\operatorname{tr}$ & - \\
\hline viridiflorene & 1496 & - & - & $\operatorname{tr}$ \\
\hline$\beta$-bisabolene & 1509 & - & 0.3 & - \\
\hline trans- $\gamma$-cadinene & 1513 & - & $\operatorname{tr}$ & - \\
\hline$\delta$-cadinene & 1524 & - & 0.2 & - \\
\hline diallyl tetrasulfide & 1540 & 17.4 & - & - \\
\hline caryophyllene oxide & 1581 & - & 0.3 & 0.2 \\
\hline 1-propyl-2-(4-thiohept-2-en-5-yl) disulfide & 1581 & 0.2 & - & - \\
\hline viridiflorol & 1590 & - & - & 0.4 \\
\hline 6-methyl-4,5,8-trithia-1,10-undecadiene & 1597 & 0.9 & - & - \\
\hline humulene epoxide II & 1607 & - & $\operatorname{tr}$ & 0.2 \\
\hline 3-amino-tert-butyl benzoate & 1620 & 0.9 & - & - \\
\hline 1-allyl-3-(2-(allylthio)propyl) trisulfane & 1818 & 2.0 & - & - \\
\hline cyclic octaatomic sulfur & 2030 & 0.2 & - & - \\
\hline 1-allyl-3-(2-(allyldisulfanyl)propyl) trisulfane & 2066 & 1.2 & - & - \\
\hline Monoterpene hydrocarbons & & - & 25.9 & 19.3 \\
\hline Oxygenated monoterpenes & & - & 64.9 & 63.5 \\
\hline Sesquiterpene hydrocarbons & & - & 8.9 & 16.4 \\
\hline Oxygenated sesquiterpenes & & - & 0.3 & 0.8 \\
\hline Nitrogen compounds & & 0.9 & - & - \\
\hline Phenylpropanoids & & - & $\operatorname{tr}$ & - \\
\hline Sulfur compounds & & 94.1 & - & - \\
\hline Other non-terpene derivatives & & - & $\operatorname{tr}$ & $\operatorname{tr}$ \\
\hline Total identified (\%): & & 95.0 & 100.0 & 100.0 \\
\hline
\end{tabular}

a , Linear retention indices on a DB5 column, ${ }^{\mathrm{b}}$, Not detected, ${ }^{\mathrm{c}}$, Traces, $<0.1 \%$. 
Sulfur compounds dominated (over 90\%) the A. sativum EO composition: diallyl trisulfide was the most abundant one, which was followed by diallyl tetrasulfide and diallyl disulfide.

The two Lamiaceae EOs, instead, were rich in oxygenated monoterpenes for which similar relative abundances were detected: 1,8-cineole and $\alpha$-thujone were the most represented compounds in R. officinalis and S. officinalis EOs, respectively. Other compounds of this chemical class showing relevant presence in both the compositions were camphor and borneol. Monoterpene hydrocarbons are followed for both these species' EOs as the second most abundant chemical class of compounds: for both $\alpha$-pinene and $\beta$-pinene, and camphene were detected in relevant relative abundances (over $2.5 \%$ ).

\subsection{Electroantennography (EAG)}

The results of Electroantennography (EAG) bioassays are reported in Figure 1. Starting from $10 \mu \mathrm{g}$ $\mu \mathrm{L}^{-1}$, A. sativum and S. officinalis EOs elicited a significantly higher EAG response on the antennae of C. vomitoria female when compared to the solvent. On the contrary, R. officinalis EO elicited a significant response only at $1000 \mu \mathrm{g} \mathrm{L}^{-1}$ (Figure 1). Overall, the two-way ANOVA showed a significant effect of the $\mathrm{EO}\left(F_{2,72}=5.646, p=0.005\right)$, while no significant difference where determined by the concentration $\left(F_{3,72}=1.952, p=0.129\right)$ with no interaction of the two factors $\left(F_{6,72}=0.232, p=0.965\right)$.

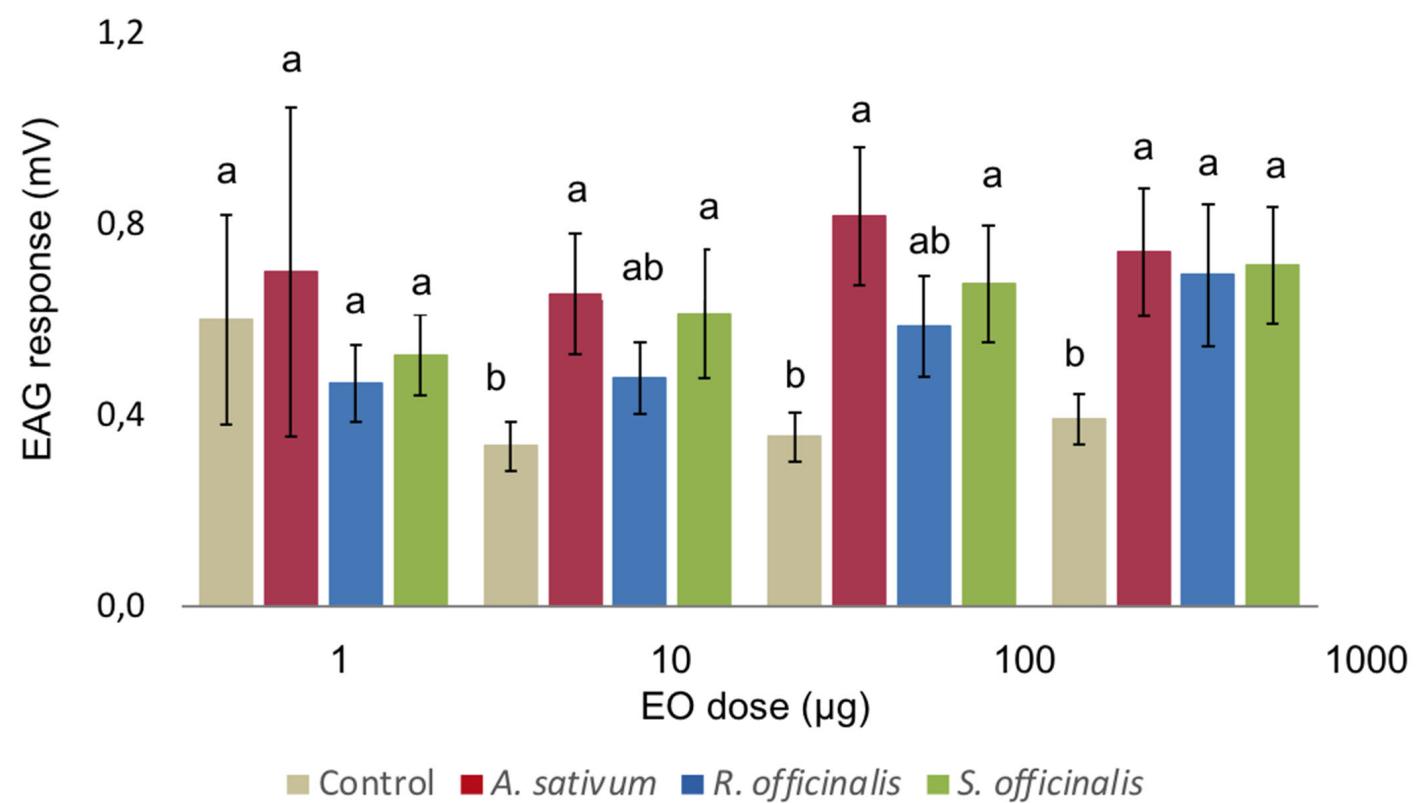

Figure 1. Mean Electroantennography responses of female C. vomitoria to puff test using $1 \mu \mathrm{L}$ of ethanol solution containing different concentrations of Allium sativum, Rosmarinus officinalis, and Salvia officinalis essential oils. Bars indicate standard error. Values labelled with different letters are significantly different by an LSD test $(p \leq 0.05)$.

\subsection{Oviposition Deterrence}

At the highest concentration $\left(5 \mu \mathrm{L} \mathrm{cm}{ }^{-2} \mathrm{EO}\right)$, all the three tested EOs showed a significant oviposition deterrence up to $72 \mathrm{~h}(\mathrm{OAI} \leq-0.3)$ and they were all able to completely avoid the oviposition on the meat by $C$. vomitoria up to $24 \mathrm{~h}$. A complete suppression of the oviposition was also observed in the meat treated with $2.50 \mu \mathrm{L} \mathrm{cm}^{-2}$ of A. sativum and S. officinalis EO whereas, at $1.25 \mu \mathrm{L}$ $\mathrm{EO} \mathrm{cm}{ }^{-2}$, only the $\mathrm{EO}$ of $A$. sativum was able to completely deter $C$. vomitoria oviposition up to $24 \mathrm{~h}$ (Figure 2). 

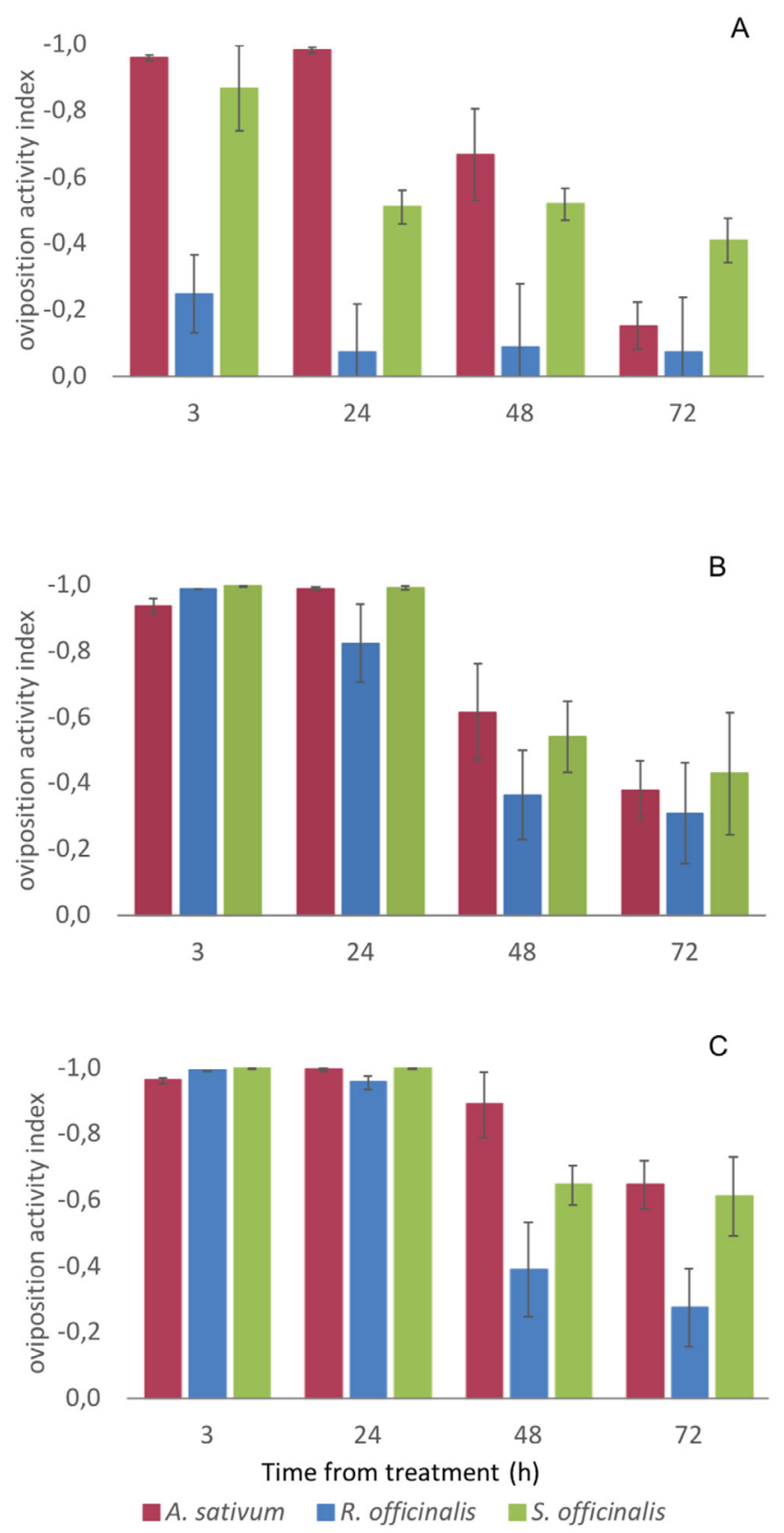

Figure 2. Oviposition deterrence of Allium sativum, Rosmarinus officinalis, and Salvia officinalis essential oils (EOs) against Calliphora vomitoria females. (A), 1.2, (B) 2.5, and (C), $5 \mu \mathrm{L} \mathrm{EO} \mathrm{cm}^{-2}$ of meat. For values $\leq-0.3$, the EO is considered significantly repellent [25]. Bars represent a standard error.

Overall, the ANCOVA showed a significant difference among the oviposition deterrence of the three EOs after controlling for the effects of the EO concentration and time of exposure $\left(F_{2,139}=10.688\right.$, $\left.p<0.001, \eta_{p}^{2}=0.133\right)$. In detail, Bonferroni post-hoc tests of the OAI EM means indicated no significant differences between A. sativum and S. officinalis EOs (OAI EM means $=-0.574 \pm 0.037$, and $-0.534 \pm$ 0.037 , respectively, $p=1.000$ ) and that the two were significantly more effective than the $R$. officinalis one (OAI EM mean $=-0.349 \pm 0.037, p=0.002)($ Table 2$)$. 
Table 2. Adjusted estimated marginal (EM) means of the oviposition activity index (OAI) of Calliphora vomitoria females on meat treated with Allium sativum, Rosmarinus officinalis, and Salvia officinalis essential oils (EOs).

\begin{tabular}{cccc}
\hline \multirow{2}{*}{ EOs } & Mean $^{\mathbf{a}} \pm \mathrm{SE}$ & \multicolumn{2}{c}{$\mathbf{9 5 \% \text { Confidence Interval }}$} \\
\cline { 3 - 4 } & & Lower Bound & Upper Bound \\
\hline A. sativum & $-0.574 \pm 0.037$ & -0.646 & -0.501 \\
R. officinalis & $-0.349 \pm 0.037$ & -0.422 & -0.277 \\
S. officinalis & $-0.534 \pm 0.037$ & -0.606 & -0.461 \\
\hline
\end{tabular}

a Data are expressed as $\mathrm{OAI} \pm$ standard error. Covariates (dose and time of exposure) are evaluated at the following values: EOs concentration $=0.875 \mu \mathrm{LEO} \mathrm{cm}{ }^{-2}$ of meat, Time $=36.75 \mathrm{~h}$.

\subsection{Ovicidal Bioassays}

After $24 \mathrm{~h}, 94 \%$ of control eggs hatched while we observed an inhibition of hatching of the eggs treated with the EOs with differences depending on the EOs $\left(F_{2,48}=452.72, p<0.001\right)$, the concentration $\left(F_{7,48}=45.268, p<0.001\right)$, and interaction EOs $x$ concentration $\left(F_{14,48}=21.894, p<0.001\right)$. Among the three tested EOs, the $A$. sativum one was the most effective (Tukey's hsd test, $p<0.001$ ) with a complete inhibition of the hatching starting from $0.16 \mu \mathrm{L} \mathrm{EO} \mathrm{cm}^{-2}$ (Figure 3).

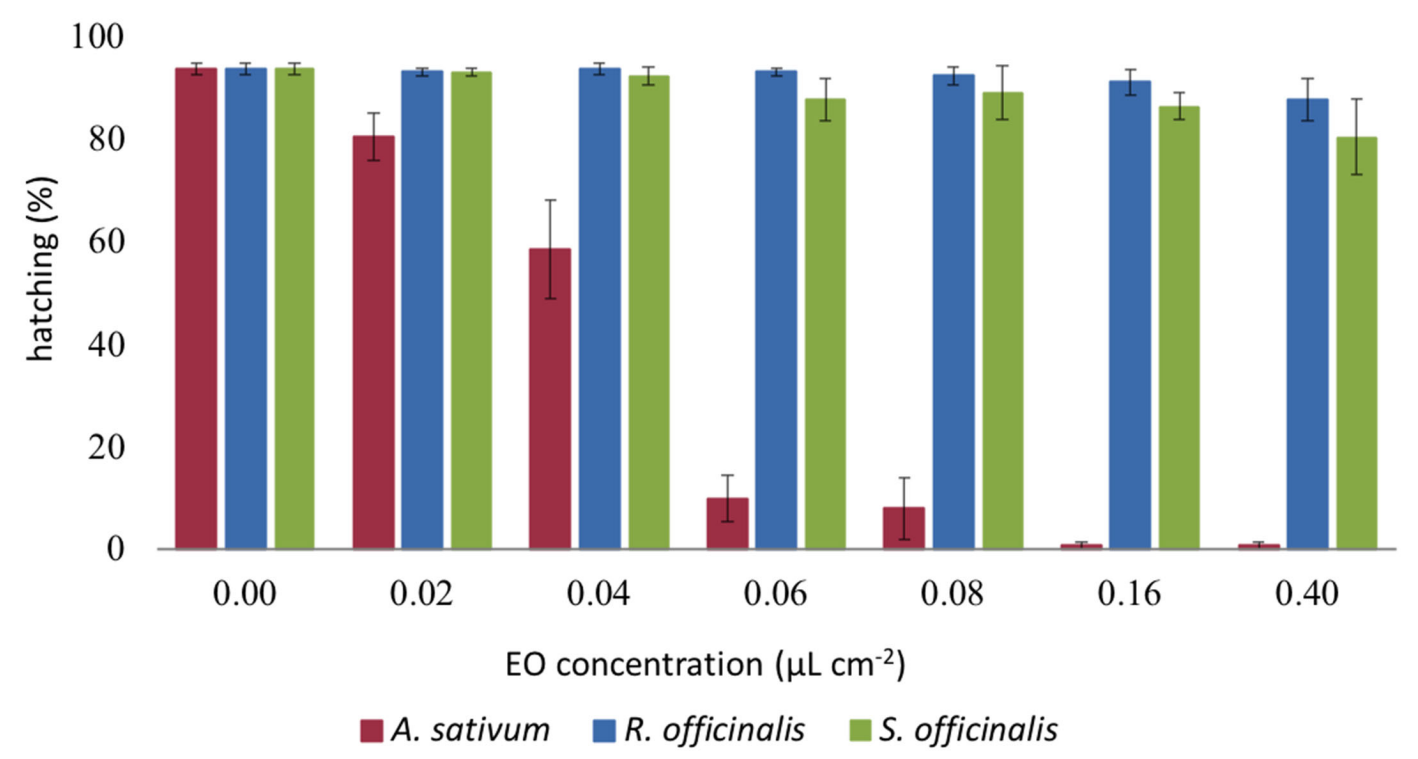

Figure 3. Ovicidal effect of Allium sativum, Rosmarinus officinalis, and Salvia officinalis essential oils. Data are expressed as a mean percentage of eggs hatching. Bars represent the standard error.

\subsection{Adulticidal Bioassays}

The EOs exerted toxic activity by both topical application and fumigation against adults of C. vomitoria (Figure 4). 

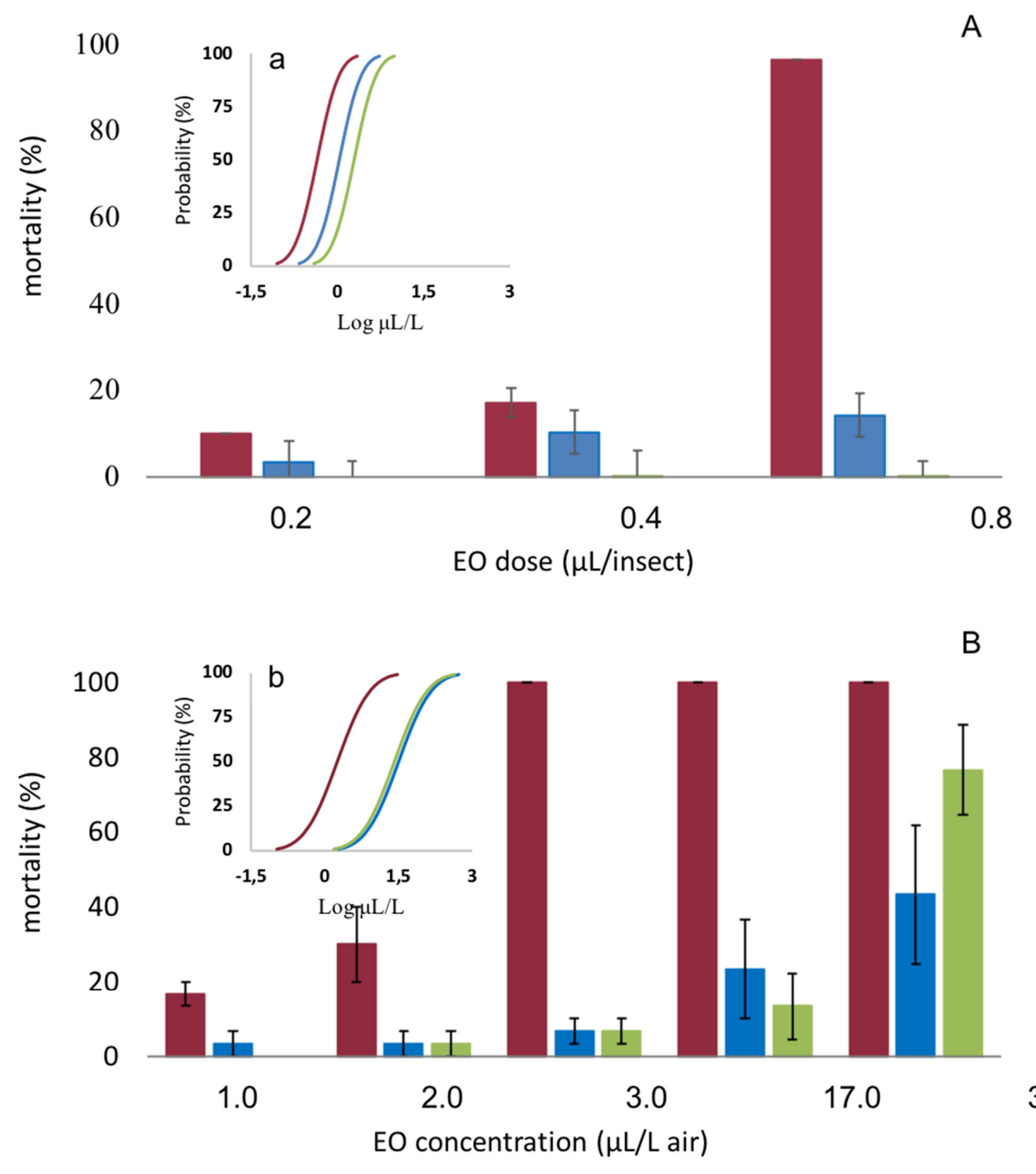

33.0

$\square$ Asativum $\square$ R. officinalis $\square$ S. officinalis

Figure 4. Mean mortality of Calliphora vomitoria adults exposed by topical application (A) and fumigation (B) to Allium sativum, Rosmarinus officinalis, and Salvia officinalis essential oils. Bars represent the standard error. Embedded graphics show the probability of mortality of the insects exposed to the EOs by topical application (a) and by fumigation (b) calculated by Log-Probit regression.

By using a topical application, the toxicity depended on the EOs $\left(F_{2,18}=48.560 ; p<0.001\right)$, the dose $\left(F_{2,18}=38.743, p<0.001\right)$, and, with significant interaction, EOs $x$ dose $\left(F_{4,18}=13.530\right.$; $p<0.001)$. Post-hoc tests indicated a significant higher toxicity of A. sativum compared to R. officinalis and S. officinalis EOs (Tukey's hsd test, $p<0.001$ ) and a higher toxicity of R. officinalis than S. officinalis EOs (Tukey's hsd test, $p<0.017)$. Median lethal dose $\left(\mathrm{LD}_{50}\right)$ values calculated by Probit analysis were $0.44,1.10$, and $1.97 \mu \mathrm{L} \mathrm{L}^{-1}$ air for A. sativum, R. officinalis, and S. officinalis EOs, respectively (Table 3). RMP analysis showed that $A$. sativum was significantly more effective than the $R$. officinalis (A. sativum vs. R. officinalis RMP $=0.400,95 \%$ CI: $0.007,0.922)$ and the S. officinalis EOs (A. sativum vs. S. officinalis $\mathrm{RMP}=0.224,95 \% \mathrm{CI}: 0.000,0.738)$. 
Table 3. Toxicity by topical application of Allium sativum, Rosmarinus officinalis, and Salvia officinalis essential oils (EOs) against adults of Calliphora vomitoria.

\begin{tabular}{ccccc}
\hline EO & $\mathbf{L D}_{\mathbf{5 0}}{ }^{\mathbf{a}}$ & $\mathbf{L D}_{\mathbf{9 5}}{ }^{\mathbf{b}}$ & Intercept & $\boldsymbol{p}$ \\
\hline A. sativum & $0.44(0.23-1.02)$ & $1.37(0.72-56.79)$ & 1.186 & $<0.001$ \\
R. officinalis & $1.10(0.60-10.70)$ & $3.43(1.40-807.14)$ & -0.138 & 0.544 \\
S. officinalis & $1.97(0.79-74.88)$ & $6.13(1.87-5502.96)$ & -0.978 & 0.001 \\
\hline
\end{tabular}

a , Concentration of the EO that kills $50 \%$ of the exposed flies. ${ }^{b}$, Dose of the EO that kills $95 \%$ of the exposed flies. Data are expressed as $\mu \mathrm{L}$ insect ${ }^{-1}$. In bracket, confidence interval. Pearson goodness of fit test: $\chi 2=16.353, \mathrm{df}=$ $5, p=0.006$. Since the significance level $(p)$ is less than 0.150 , a heterogeneity factor is used in the calculation of confidence limits.

By fumigation, the A. sativum EO killed all the fly population starting from $3.0 \mu \mathrm{L} \mathrm{L}^{-1}$ air (Figure 4). The toxicity of the EOs was dependent on the EOs $\left(F_{2,36}=65.117, p<0.001\right)$, the concentration $\left(F_{5,36}\right.$ $=36.938, p<0.001)$, and with significant interaction EOs $x$ concentration $\left(F_{10,36}=7.299, p<0.001\right)$. We observed a much higher activity of the A. sativum EO with respect to the others (Tukey's hsd test, $p<0.001)$. Median lethal concentration $\left(\mathrm{LC}_{50}\right.$ ) values calculated by Probit analysis were $1.76,31.52$, and $25.52 \mu \mathrm{L} \mathrm{L}^{-1}$ air for A. sativum, R. officinalis, and S. officinalis EOs, respectively (Table 4). RMP analysis showed that $A$. sativum was significantly more effective than the $R$. officinalis (A. sativum vs. $R$. officinalis $\mathrm{RMP}=0.056,95 \% \mathrm{CI}: 0.00,0.367)$ and S. officinalis EOs (A. sativum vs S. officinalis RMP $=0.069,95 \%$ CI: $0.00,0.421)$.

Table 4. Toxicity by fumigation of Allium sativum, Rosmarinus officinalis, and Salvia officinalis essential oils (EOs) against adults of Calliphora vomitoria.

\begin{tabular}{ccccc}
\hline EO & LC $_{\mathbf{5 0}}{ }^{\mathbf{a}}$ & $\mathbf{L C}_{\mathbf{9 5}} \mathbf{b}^{\mathbf{b}}$ & Intercept & $\boldsymbol{p}$ \\
\hline A. sativum & $1.76(0.62-4.12)$ & $13.04(5.30-109.21)$ & -0.467 & 0.002 \\
R. officinalis & $31.52(12.87-133.39)$ & $232.90(70.04-5513.08)$ & -2.838 & $<0.001$ \\
S. officinalis & $25.52(10.39-96.36)$ & $188.55(59.34-3793.51)$ & -2.664 & $<0.001$ \\
\hline
\end{tabular}

a Concentration of the EO that kills $50 \%$ of the exposed flies. ${ }^{b}$ Concentration of the EO that kills $95 \%$ of the exposed flies. Data are expressed as $\mu \mathrm{L} \mathrm{L}^{-1}$ air. In bracket, there is a confidence interval. Pearson goodness of fit test: $\chi 2$ $=56.151, \mathrm{df}=11, p<0.001$. Since the significance level $(p)$ is less than 0.150 , a heterogeneity factor is used in the calculation of confidence limits.

An overall significant linear relationship between the concentration/dose of the EOs and the mortality of the flies was observed by both fumigation and topical application $\left(R=0.636, F_{1,52}=35.254\right.$, $p<0.001$, and $R=0.522, F_{1,52}=9.374, p=0.005$ for fumigation and topical application, respectively).

\subsection{Antimicrobial Activity}

The MIC and MLC values showed that the most generally susceptible microbial pathogens were B. subtilis and S. aureus with MIC and MLC values for A. sativum and S. officinalis EOs lower than $0.63 \mu \mathrm{L} \mathrm{mL}{ }^{-1}$. The most resistant microbial strain was $S$. enterica with values of $10 \mu \mathrm{L} \mathrm{mL}^{-1}$ or above for all the three EOs (Table 5). 
Table 5. Minimum inhibitory concentration (MIC) and minimum lethal concentration (MLC) values of the essential oils of Allium sativum, Rosmarinus officinalis, and Salvia officinalis against Escherichia coli, Bacillus subtilis, Streptococcus aureus, Candida albicans, and Salmonella enterica microbial strains.

\begin{tabular}{lcccccc}
\hline \multirow{2}{*}{ Microorganism } & \multicolumn{2}{c}{ A. sativum } & \multicolumn{2}{c}{ R. officinalis } & \multicolumn{2}{c}{ S. officinalis } \\
\cline { 2 - 7 } & MIC & MLC & MIC & MLC & MIC & MLC \\
\hline E. coli & $1.25^{\text {a }}$ & 1.25 & 2.50 & 2.50 & 5.00 & 5.00 \\
B. subtilis & $<0.63$ & $<0.63$ & 1.25 & 2.50 & $<0.63$ & $<0.63$ \\
S. aureus & $<0.63$ & $<0.63$ & 2.50 & 5.00 & $<0.63$ & $<0.63$ \\
C. albicans & 1.25 & 5.00 & 1.25 & 1.25 & $>10.00$ & $>10.00$ \\
P. aeruginosa & 1.25 & 1.25 & 2.50 & 2.50 & $<0.63$ & $<0.63$ \\
S. enterica & 10.00 & 10.00 & $>10.00$ & $>10.00$ & $>10.00$ & $>10.00$ \\
\hline \multicolumn{3}{c}{ a, Values are given as $\mu \mathrm{LL}^{-1 .}$}
\end{tabular}

\subsection{EO-Charged Mist Assay}

The olfactive barrier created by the EO-charged mist significantly reduced the number of Diptera captured inside of the meat processing plant (Figure 5). The t-test showed that the Calliphoridae $\left(\mathrm{t}_{4}=3.590, p=0.023\right)$ and the Muscidae $\left(\mathrm{t}_{4}=4.061, p=0.015\right)$ as well as the Total Diptera trapped $\left(\mathrm{t}_{4}=4.591 ; p=0.010\right)$ were significantly lower when the EO emulsion was sprayed at the entrance of the processing plants.

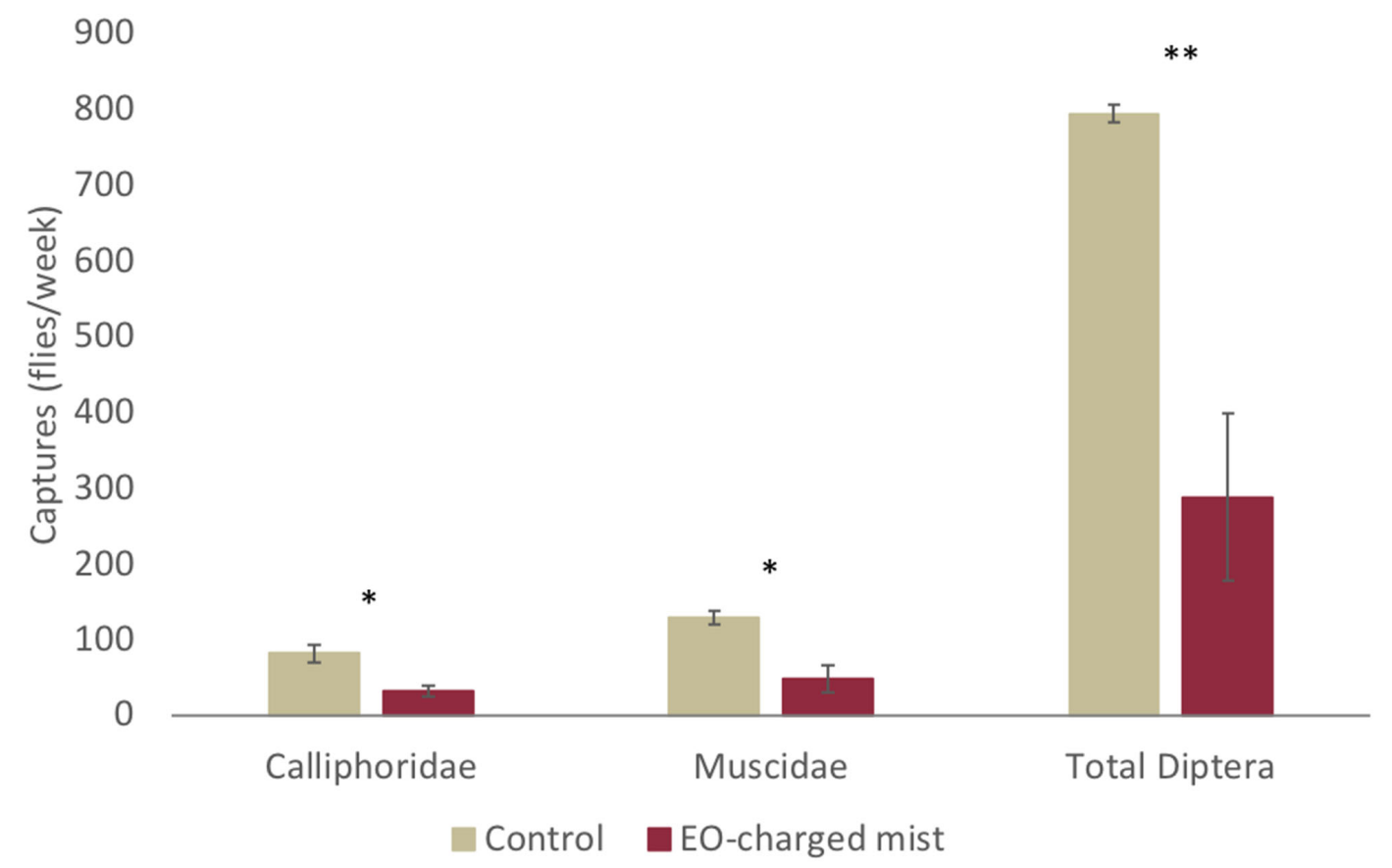

Figure 5. Mean number of flies trapped inside the meat processing room during the treatment of the plant entrance tunnel by the EOs-charged or control mist. Bars represent a standard error. Asterisks indicate a significant difference between the treatments for each category by t-test $\left({ }^{*}, P \leq 0.05\right.$; **, $P \leq 0.01)$.

\section{Discussion}

EO and spice extracts have found widespread use in the food industry not only for their aroma and colouring, but also for their preservative properties and for the beneficial effects for the health of consumers [13,31]. However, despite the fact that it has been shown that spice EOs are also toxic and repellent against food insect pests, very little is known today about their use against synanthropic flies. In this case, for the first time, we tested the EOs of three of the most widely used spices as 
insecticides and repellents against the blowfly $C$. vomitoria a pest of meat products and a vector of foodborne diseases.

The chemical compositions of the EOs tested in this study are consistent with the results obtained in the EAG assay. Generally, since the EAG response is linked to the insect olfaction, it is reasonable that this was primarily elicited by the more volatile fraction of the extracts as reported for other dipteran species [32,33]. In our experiments, the A. sativum EO elicited an overall stronger EAG response than the other two EOs tested. Nevertheless, there was not a clear concentration dependent response, as observed in other dose response experiments, using EOs as stimuli [34]. Compared with the solvent, A. sativum and S. officinalis EOs determined significant antennal responses from the concentration of $10 \mu \mathrm{g} \mu \mathrm{L}^{-1}$, while EAG responses at $1 \mu \mathrm{g} \mu \mathrm{L}^{-1}$ were similar to the solvent, which indicates a threshold of perception for these EOs concentrations. In the case of the A. sativum EO, such a prompt response elicited on the $C$. vomitoria female antennae could be determined by the relatively high amount of sulphur compound volatiles (about 94\%) in the EO composition. In fact, Calliphora spp. flies are known to be very sensitive to sulphur compounds as dimethyl trisulphide [35,36]. On the other hand, the EAG responses elicited on $C$. vomitoria antennae by the $S$. officinalis $\mathrm{EO}$ are more likely determined by the terpenes fraction as reported for the housefly Musca domestica L. [37].

The responsiveness of $C$. vomitoria to the three EOs was confirmed by the results of the oviposition deterrence bioassay that showed that A. sativum, R. officinalis, and S. officinalis EOs are able to exert a clear deterrent activity against $C$. vomitoria females' oviposition. Such results are in good agreement with previous experiments showing a strong oviposition deterrence by Artemisia dracunculus L. and A. annua L. (Asteraceae) EOs [19] against C. vomitoria and of Lavandula angustifolia Mill., and Clinopodium nubigenum (Kunth) EOs against Lucilia sericata Meigen (Diptera Calliphoridae) [28]. A repellent effect of EOs was also observed by Callander and James [38] who obtained the complete inhibition of oviposition of L. cuprina on wool treated with tea tree (Melaleuca alternifolia Maiden \& Betche) EO. In comparison with the Artemisia species, the EOs extracted from the three spices utilized in this work were less effective as oviposition deterrent. However, it should be highlighted that the use of EOs extracted from aromatic plants widely used as spices has the advantage that they are allowed in the food industry as ingredients [39]. In addition to oviposition deterrence, we also observed a strong toxicity of the A. sativum EO against adults and eggs of C. vomitoria that was significantly higher than those of the $R$. officinalis and $S$. officinalis ones. In line with our results, the $A$. sativum extract was recently found to be toxic to blowflies' larvae [40] and a clear ovicidal action of $A$. sativum EO has also been reported on the coleopteran Callosobruchus maculatus F. [41]. The higher bioactivity against C. vomitoria of the A. sativum among the tested EOs could be due to the presence of diallyl trisulfide and methyl allyl trisulfide, which are the $A$. sativum EO main compounds. Such substances were isolated and tested for their bioactivities as oviposition deterrent and adulticidal agents against the coleopteran Sitophilus zeamais Motschulsky and Tribolium castaneum Herbst. Both the compounds inhibited or reduced the egg hatching. Moreover, diallyl trisulfide and methyl allyl trisulfide showed adulticidal activity both by contact and fumigation as well as anti-feedant activity [42]. In the present study, however, a holistic approach without isolation of the main compounds has been preferred and the entire EO has been used. Published literature reports higher efficacy for complete EOs, including their minor compounds, whose presence seems synergic for the overall bioactivity $[43,44]$. On the other hand, as already mentioned above, the use of the whole EO instead of its purified active compounds may be preferable since EOs are natural extracts of spices allowed in the food production.

The antimicrobial assays performed in this study showed that the EOs besides their toxic and repellent effect against the insect pests are also able to exert a strong antimicrobial activity against various bacterial and fungal human pathogens. In particular, among the foodborne disease bacteria, we observed a strong activity against $E$. coli, while $S$. enterica was the most resistant strain. In line with these results, S. enterica was found to be the most resistant microbial strain for the EOs extracted from C. nubigenum and L. angustifolia [28]. Such antimicrobial activity of the EOs is important since Calliphoridae are vectors of numerous microorganisms and foodborne pathogens [1-3]. Landing on 
the meat for feeding or for oviposition, they can easily contaminate the food, which causes the spread of foodborne diseases and the rotting of the product.

On the basis of the results obtained in the oviposition deterrence and toxicity bioassays, we have selected the A. sativum EO to be tested as an active ingredient in an EO-charged mist sprayed in the entryway tunnel of a ham factory in order to form an olfactory barrier able to control the entrance of the flies in the meat processing room. This usually occurs when the doors are open to allow the unloading of the fresh meat and the loading of the hams. Even if EOs have been extensively studied as topical repellent against insects of medical or veterinary importance [20,45-47], and proposed as repellents in food packaging [48-51] and stored foodstuff [18,44,52], to the best of our knowledge, this is the first report on the use of an EO-charged mist as an olfactory barrier to protect an indoor working space from the entrance of problematic flies. In line with our results, however, a good efficacy of the EOs as aerosol spray have been reported by Revay et al. [53] who observed that a timed-released $0.3 \%$ aqueous geraniol emulsion significantly reduced mosquito-biting pressure of Culex pipiens $\mathrm{L}$. and Aedes albopictus Skuse (Diptera: Culicidae) in outdoor conditions. Compared to a direct use of the EOs as treatment of the food, the EO-charged mist has the advantage that the EO is not in direct contact with the food and, by consequence, there is no alteration of its chemical and organoleptic properties.

\section{Conclusions}

Insect pests and food-borne diseases represent a growing economic and public health problem worldwide. Thanks to their high availability, low cost, and acceptance as ingredients in food preparation, spice EOs may represent excellent repellents and insecticides to be used in food processing plants. Our results indicate that selected spice EOs may act as an effective low-cost natural shield able to control the presence of problematic flies into food processing rooms in order to protect meat and fish products from blowflies' infestation and microbial contamination by both direct application on food and sprayed to form an olfactory barrier.

Supplementary Materials: The following are available online at http://www.mdpi.com/2075-4450/11/3/143/s1. Figure S1: Disposition in the cage bottom of the embedding moulds filled by meshed meat treated with one of the tested essential oils (EOs) for the oviposition deterrence test. Each unit of four moulds treated with different EO concentrations $\left(0.0,1.2,2.5\right.$, and $\left.5 \mu \mathrm{L} \mathrm{cm}^{-2}\right)$ was repeated at each of the cage corner.

Author Contributions: Conceptualization, B.C. and S.B. Methodology, A.L., B.C., G.F., M.C.E., R.A., S.B., and S.G. Formal analysis, S.B. and S.G. Investigation, A.L., B.C., G.F., M.C.E., R.A., S.B., and S.G. Writing-original draft preparation, R.A., S.B., and S.G. Writing-review and editing, A.L., B.C., G.F., M.C.E., R.A., S.B., and S.G. Supervision, B.C. Funding acquisition, B.C. All authors have read and agreed to the published version of the manuscript.

Funding: The Italian Ministry of Education, University and Research (MIUR), BIOPIC, 2015BABFCF, funded this work.

Acknowledgments: The authors wish to thank the ham factory Micheletti Srl (Lammari, Lucca, Italy) for hosting the EO-charged mist experiment in their meat processing plant, the Freezanz System Srl (Pisa, Italy) for the supply of the mist sprayer system, and Paolo Giannotti for technical assistance. The authors also thank Mokhtar Abdulsattar Arif for his helpful assistance during the electroantennography experiments.

Conflicts of Interest: The authors declare no conflict of interest.

\section{References}

1. Pava-Ripoll, M.; Pearson, R.E.G.; Miller, A.K.; Ziobro, G.C. Prevalence and relative risk of Cronobacter spp., Salmonella spp., and Listeria monocytogenes associated with the body surfaces and guts of individual filth flies. Appl. Environ. Microbiol. 2012, 78, 7891-7902. [CrossRef]

2. Greenberg, B. Flies and Disease. Vol. I. Ecology, Classification and Biotic Associations; Princeton University Press: Princeton, NJ, USA, 1971.

3. Graczyk, T.K.; Knight, R.; Gilman, R.H.; Cranfield, M.R. The role of non-biting flies in the epidemiology of human infectious diseases. Microbes Infect. 2001, 3, 231-235. [CrossRef] 
4. Hall, M.J.; Smith, K.G. Diptera causing myiasis in man. In Medical Insects and Arachnids; Springer: Dordrecht, The Netherlands, 1993; pp. 429-469.

5. Francesconi, F.; Lupi, O. Myiasis. Clin. Microbiol. Rev. 2012, 25, 79-105. [CrossRef]

6. Paczkowski, S.; Maibaum, F.; Paczkowska, M.; Schütz, S. Decaying Mouse Volatiles Perceived by Calliphora vicina Rob.-Desv. J. Forensic Sci. 2012, 57, 1497-1506. [CrossRef]

7. Deonier, C.C. Carcass temperatures and their relation to winter blowfly populations and activity in the Southwest. J. Econ. Entomol. 1940, 33, 166-170. [CrossRef]

8. Faucherre, J.; Cherix, D.; Wyss, C. Behavior of Calliphora vicina (Diptera, Calliphoridae) under extreme conditions. J. Insect Behav. 1999, 12, 687-690. [CrossRef]

9. Gu, R.Y.; Liu, H.; Fu, W.C. Study on pork preservation by essential oil from perfume material. J. Food Sci. 2007, 8, 498-500.

10. Babuskin, S.; Babu, P.A.S.; Sasikala, M.; Sabina, K.; Archana, G.; Sivarajan, M.; Sukumar, M. Antimicrobial and antioxidant effects of spice extracts on the shelf life extension of raw chicken meat. Int. J. Food Microbiol. 2014, 171, 32-40.

11. De La Torre Torres, J.E.; Gassara, F.; Kouassi, A.P.; Brar, S.K.; Belkacemi, K. Spice use in food: Properties and benefits. Crit. Rev. Food Sci. Nutr. 2017, 57, 1078-1088.

12. Tajkarimi, M.M.; Ibrahim, S.A.; Cliver, D.O. Antimicrobial herb and spice compounds in food. Food Control 2010, 21, 1199-1218. [CrossRef]

13. Gottardi, D.; Bukvicki, D.; Prasad, S.; Tyagi, A.K. Beneficial effects of spices in food preservation and safety. Front. Microbiol. 2016, 7, 1394. [CrossRef]

14. Isman, M.B. Plant essential oils for pest and disease management. Crop Prot. 2000, 19, 603-608. [CrossRef]

15. Isman, M.B. Botanical insecticides, deterrents, and repellents in modern agriculture and an increasingly regulated world. Annu. Rev. Entomol. 2006, 51, 45-66. [CrossRef]

16. Nerio, L.S.; Olivero-Verbel, J.S.; Tashenko, E. Repellent activity of essential oils from seven aromatics plants grown in Colombia against Sitophilus zeamais Motschulsky (Coleoptera). J. Stored Prod. Res. 2009, 45, $212-214$. [CrossRef]

17. Benelli, G.; Canale, A.; Conti, B. Eco-friendly control strategies against the asian tiger mosquito, Aedes albopictus (Diptera: Culicidae): Repellency and toxic activity of plant essential oils and extracts. Pharmacologyonline 2014, 1, 44-51.

18. Bedini, S.; Flamini, G.; Girardi, J.; Cosci, F.; Conti, B. Not just for beer: Evaluation of spent hops (Humulus lupulus) as a source of eco-friendly repellents for insect pests of stored foods. J. Pest. Sci. 2015, 88, 583-592. [CrossRef]

19. Bedini, S.; Flamini, G.; Cosci, F.; Ascrizzi, R.; Echeverria, M.C.; Guidi, L.; Landi, M.; Lucchi, A.; Conti, B. Artemisia spp. essential oils against the disease-carrying blowfly Calliphora vomitoria. Parasites Vectors 2017, 10, 80. [CrossRef]

20. Bedini, S.; Flamini, G.; Ascrizzi, R.; Venturi, F.; Ferroni, G.; Bader, A.; Girardi, J.; Conti, B. Essential oils sensory quality and their bioactivity against the mosquito Aedes albopictus. Sci. Rep. 2018, 8, 17857. [CrossRef]

21. Linstrom, P.J. Nist standard reference database number 69. In NIST Chemistry WebBook; Linstrom, P.J., Mallard, W.G., Eds.; National Institute of Standards and Technology: Gaithersburg, MD, USA, 2014. [CrossRef]

22. Adams, R.P. Identification of Essential Oil Components by Gas Chromatography/Mass Spectroscopy, 4th ed.; Carol Stream Allured Publ. Corp.: Carol Stream, IL, USA, 2007; Volume 456.

23. Davies, N.W. Gas chromatographic retention indices of monoterpenes and sesquiterpenes on methyl silicon and carbowax $20 \mathrm{M}$ phases. J. Chromatogr. 1990, 503, 1-24. [CrossRef]

24. Cheah, S.X.; Tay, J.W.; Chan, L.K.; Jaal, Z. Larvicidal, oviposition, and ovicidal effects of Artemisia annua (Asterales: Asteraceae) against Aedes aegypti, Anopheles sinensis, and Culex quinquefasciatus (Diptera: Culicidae). Parasitol. Res. 2013, 112, 3275-3282. [CrossRef]

25. Kramer, W.L.; Mulla, S. Oviposition attractants and repellents of mosquitoes: Oviposition responses of Culex mosquitoes to organic infusions. Environ. Entomol. 1979, 8, 1111-1117. [CrossRef]

26. Pascual-Villalobos, M.J. Evaluation of insecticidal activity of Chrysantemum coronarium L. plant extracts. Bol. San.Veg. Plagas. 1996, 22, 411-420.

27. Abbot, W.J. A method of computing effectiveness of an insecticide. J. Econ. Entomol. 1925, 18, $256-267$. [CrossRef] 
28. Bedini, S.; Flamini, G.; Cosci, F.; Ascrizzi, R.; Echeverria, M.C.; Gomez, E.V.; Guidi, L.; Landi, M.; Lucchi, A.; Conti, B. Toxicity and oviposition deterrence of essential oils of Clinopodium nubigenum and Lavandula angustifolia against the myiasis-inducing blowfly Lucilia sericata. PLoS ONE 2019, 14, e0212576. [CrossRef]

29. Cos, P.; Vlietinck, A.J.; Berghe, D.V.; Maes, L. Anti-infective potential of natural products: How to develop a stronger in vitro 'proof-of-concept'. J. Ethnopharmacol. 2006, 106, 290-302. [CrossRef]

30. Oosterbroek, P. The European Families of the Diptera: Identification-Diagnosis-Biology; KNNV Publishing: Uthrecht, The Netherlands, 2006; p. 205.

31. Sultana, S.; Ripa, F.A.; Hamid, K. Comparative antioxidant activity study of some commonly used spices in Bangladesh. Pak. J. Biol. Sci. 2010, 13, 340. [CrossRef]

32. Zhao, Y.X.; Kang, L.E. Role of plant volatiles in host plant location of the leafminer, Liriomyza sativae (Diptera: Agromyzidae). Physiol. Entomol. 2002, 27, 103-111. [CrossRef]

33. Ghabbari, M.; Guarino, S.; Caleca, V.; Saiano, F.; Sinacori, M.; Baser, N.; Mediouni-Ben Jemâa, J.; Lo Verde, G. Behavior-modifying and insecticidal effects of plant extracts on adults of Ceratitis capitata (Wiedemann) (Diptera Tephritidae). J. Pest Sci. 2018, 91, 907-917. [CrossRef]

34. Romani, R.; Bedini, S.; Salerno, G.; Ascrizzi, R.; Flamini, G.; Echeverria, M.C.; Farina, P.; Conti, B. Andean Flora as a source of new repellents against insect pests: Behavioral, morphological and electrophysiological studies on Sitophilus zeamais (Coleoptera: Curculionidae). Insects 2019, 10, 171. [CrossRef]

35. Nilssen, A.C.; Tømmerås, B.Å.; Schmid, R.; Evensen, S.B. Dimethyl trisulphide is a strong attractant for some calliphorids and a muscid but not for the reindeer oestrids Hypoderma tarandi and Cephenemyia trompe. Entomol. Exp. Et Appl. 1996, 79, 211-218. [CrossRef]

36. Zito, P.; Sajeva, M.; Raspi, A.; Dötterl, S. Dimethyl disulfide and dimethyl trisulfide: So similar yet so different in evoking biological responses in saprophilous flies. Chemoecology 2014, 24, 261-267. [CrossRef]

37. Zito, P.; Guarino, S.; Peri, E.; Sajeva, M.; Colazza, S. Electrophysiological and behavioural responses of the housefly to "sweet" volatiles of the flowers of Caralluma europaea (Guss.) NE Br. Arthropod Plant Interact. 2013, 7, 485-489. [CrossRef]

38. Callander, J.T.; James, P.J. Insecticidal and repellent effects of tea tree (Melaleuca alternifolia) oil against Lucilia cuprina. Vet Parasitol. 2012, 184, 271-278. [CrossRef]

39. Hirasa, K.; Takemasa, M. Spice Science and Technology; CRC Press: Boca Raton, FL, USA, 1998.

40. Wahyuni, D.; Sari, N.P.; Hanjani, D.L. White Onion (Allium sativum) Extract as a Vegetable Larvicide in Blowfly (Calliphoridae) Control. J. Kesehat. Masy. 2019, 15, 2.

41. Denloye, A.A. Bioactivity of powder and extracts from garlic, Allium sativum L. (Alliaceae) and spring onion, Allium fistulosum L. (Alliaceae) against Callosobruchus maculatus F. (Coleoptera: Bruchidae) on cowpea, Vigna unguiculata (L.) Walp (Leguminosae) seeds. Psyche A J. Entomol. 2010, 2010, 958348. [CrossRef]

42. Huang, Y.; Chen, S.X.; Ho, S.H. Bioactivities of Methyl Allyl Disulfide and Diallyl Trisulfide from Essential Oil of Garlic to Two Species of Stored-Product Pests, Sitophilus zeamais (Coleoptera: Curculionidae) and Tribolium castaneum (Coleoptera: Tenebrionidae). J. Econ. Entomol. 2000, 93, 537-543. [CrossRef]

43. Miresmailli, S.; Bradbury, R.; Isman, M.B. Comparative toxicity of Rosmarinus officinalis L. essential oil and blends of its major constituents against Tetranychus urticae Koch (Acari: Tetranychidae) on two different host plants. Pest Manag. Sci. 2006, 62, 366-371. [CrossRef]

44. Bedini, S.; Bougherra, H.H.; Flamini, G.; Cosci, F.; Belhamel, K.; Ascrizzi, R.; Conti, B. Repellency of anethole-and estragole-type fennel essential oils against stored grain pests: The different twins. Bull. Insectol. 2016, 69, 149-157.

45. Oyedele, A.O.; Gbolade, A.A.; Sosan, M.B.; Adewoyin, F.B.; Soyelu, O.L.; Orafidiya, O.O. Formulation of an effective mosquito-repellent topical product from lemongrass oil. Phytomedicine 2002, 9, 259-262. [CrossRef]

46. Nerio, L.S.; Olivero-Verbel, J.; Stashenko, E. Repellent activity of essential oils: A review. Bioresour. Technol. 2010, 101, 372-378. [CrossRef]

47. Debboun, M.; Strickman, D. Insect repellents and associated personal protection for a reduction in human disease. Med. Vet. Entomol. 2013, 27, 1-9. [CrossRef]

48. Wong, K.K.; Signal, F.A.; Campion, S.H.; Motion, R.L. Citronella as an insect repellent in food packaging. J. Agric. Food Chem. 2005, 53, 4633-4636. [CrossRef]

49. Bougherra, H.H.; Bedini, S.; Flamini, G.; Cosci, F.; Belhamel, K.; Conti, B. Pistacia lentiscus essential oil has repellent effect against three major insect pests of pasta. Ind. Cro. Prod. 2015, 63, 249-255. [CrossRef] 
50. Licciardello, F.; Muratore, G.; Suma, P.; Russo, A.; Nerín, C. Effectiveness of a novel insect-repellent food packaging incorporating essential oils against the red flour beetle (Tribolium castaneum). Innov. Food Sci. Emerg. Technol. 2013, 19, 173-180. [CrossRef]

51. Kim, J.; Park, N.H.; Na, J.H.; Han, J. Development of natural insect-repellent loaded halloysite nanotubes and their application to food packaging to prevent Plodia interpunctella infestation. J. Food Sci. 2016, 81, E1956-E1965. [CrossRef]

52. Pierattini, E.C.; Bedini, S.; Venturi, F.; Ascrizzi, R.; Flamini, G.; Bocchino, R.; Girardi, J.; Giannotti, P.; Ferroni, G.; Conti, B. Sensory quality of essential oils and their synergistic effect with diatomaceous earth, for the control of stored grain insects. Insects 2019, 10, 114. [CrossRef]

53. Revay, E.E.; Junnila, A.; Kline, D.L.; Xue, R.D.; Bernier, U.R.; Kravchenko, V.D.; Yefremova, Z.A.; Müller, G.C. Reduction of mosquito biting pressure by timed-release $0.3 \%$ aerosolized geraniol. Acta Trop. 2012, 124, 102-105. [CrossRef]

(C) 2020 by the authors. Licensee MDPI, Basel, Switzerland. This article is an open access article distributed under the terms and conditions of the Creative Commons Attribution (CC BY) license (http://creativecommons.org/licenses/by/4.0/). 